\title{
Substitusi Silase Secara Kimiawi Limbah Padat Surimi Ikan Swanggi (Priacanthus macracanthus) Pada Tepung Ikan Terhadap Retensi Protein Dan Retensi Lemak Ikan Nila (Oreochromis niloticus)
}

\section{Silage substitution Chemically Solid Waste Surimi Fish Swanggi (Priacanthus macracanthus) on to Retention Protein Fish Meal and Retention Fat Tilapia (Oreochromis niloticus)}

Sri Subekti ${ }^{1}$, Muhammad Arief ${ }^{1}$ dan Galih Candra Prakosa Yudha ${ }^{2} *$

${ }^{1}$ Departemen Manajemen Kesehatan Ikan dan Budidaya Perairan, Fakultas Perikanan dan Kelautan Universitas Airlangga, Surabaya

${ }^{2}$ Program Studi Budidaya Perairan, Fakultas Perikanan dan Kelautan Universitas Airlangga, Surabaya

*galih-c-p-10@fpk.unair.ac.id

Ikan nila (Oreochromis niloticus) merupakan suatu komoditas perikanan air tawar yang bernilai ekonomis. Permasalahan yang saat ini dihadapi dalam budidaya ikan nila adalah harga bahan pakan terutama tepung ikan semakin mahal. Upaya yang dapat dilakukan adalah menggantikan tepung ikan dengan limbah padat surimi ikan swanggi (Priacanthus macracanthus) secara kimiawi. Penelitian yang dilakukan bertujuan untuk mengetahui pengaruh substitusi limbah padat surimi ikan swanggi (Priaacanthus macracanthus) secara kimiawi pada tepung ikan terhadap laju pertumbuhan dan efisiensi pakan ikan nila (Oreochromis niloticus). Penelitian ini menggunakan metode eksperimental dengan Rancangan Acak Lengkap (RAL). Analisa statistik menggunakan Analysis of Variant (ANOVA) supaya dapat mengetahui pengaruh perlakuan. Berdasarkan hasil penelitian didapatkan hasil bahwa substitusi limbah padat dari surimi ikan swanggi (Priacanthus macracanthus) secara kimia pada tepung ikan tidak berbeda nyata $(\mathrm{p}>0,05)$ terhadap retensi protein dengan nilai $\mathrm{P}_{0}(7,97), \mathrm{P}_{1}(9,26), \mathrm{P}_{2}(7,07), \mathrm{P}_{3}(11,02)$ dan retensi lemak ikan nila (Oreochromis niloticus) $\mathrm{P}_{0}(4,09), \mathrm{P}_{1}(5,67), \mathrm{P}_{2}(4,53), \mathrm{P}_{3}(6,73)$ tidak menunjukkan perbedaan yang signifikan $(\mathrm{P}>0,05)$. Kualitas air media pemeliharaan ikan nila adalah suhu $26-28{ }^{\circ} \mathrm{C}$, Oksigen terlarut 5-8 mg/l, pH 7-8, Amonia 0-1,5 mg/l.

Kata kunci: Ikan nila, limbah padat surimi, retensi protein, retensi lemak

\begin{abstract}
Tilapia (Oreochromis niloticus) is a freshwater fishery commodities that have economic value. The problems currently faced in tilapia fish farming is the price of feed ingredients, especially the more expensive fish meal. Efforts to do is replace fish meal with fish surimi swanggi solid waste (Priaacanthus macracanthus) chemically. This study aimed to determine the effect of substitution of solid waste swanggi fish surimi (Priaacanthus macracanthus) chemically in fish meal on the rate of growth and feed efficiency of tilapia (Oreochromis niloticus). This study uses an experimental method with completely randomized design (CRD). Statistical analysis using the Analysis of Variant (ANOVA) to determine the effect of treatment. Based on the results of the study showed that the substitution of solid waste swanggi fish surimi (Priacanthus macracanthus) chemical in fish meal did not significantly difference ( $\mathrm{p}>0.05$ ) on the protein fish meal in the value of $\mathrm{P}_{0}(7,97), \mathrm{P}_{1}(9,26), \mathrm{P}_{3}(7,07), \mathrm{P}_{3}(11,02)$ and retention fat tilapia (Oreochromis niloticus) $\mathrm{P}_{0}(4,09), \mathrm{P}_{1}(5,67), \mathrm{P}_{2}(4,53), \mathrm{P}_{3}(6,73)$ did not showed significantly difference $(\mathrm{P}>0.05)$. Maintenance of water quality media tilapia is $26-28^{\circ} \mathrm{C}$ temperature, dissolved oxygen $5-8 \mathrm{mg} /$ 1, $\mathrm{pH}$ 7-8, Ammonia 0-1.5 mg / 1.
\end{abstract}

Key words: Tilapia, solid waste surimi, retention protein fish meal, retention fat tilapia 


\section{Pendahuluan}

Pakan merupakan salah satu komponen penting dalam menentukan keberhasilan budidaya. Kebutuhan dalam budidaya sekitar $60 \%$ variable cost berasal dari pakan sedangkan sekitar $40 \%$ lainnya merupakan biaya pengadaan benur $10 \%$ dan sarana produksi 30\% (Mujiman, 2004). Protein sebagai salah satu komponen utama pakan ikan umumnya berasal dari tepung ikan dan bungkil kedelai yang sebagian besar yaitu produk impor dengan harga yang relatif mahal yaitu $\mathrm{Rp} 14.408$ per kg tepung ikan dan Rp 4.700 per kg bungkil kedelai. Jumlah impor tepung ikan Indonesia tahun 2011 mencapai 63.545 ton. Harga tepung ikan yang tinggi menyebabkan harga pakan menjadi tidak kompetitif sehingga dapat berdampak pada kelangsungan usaha budidaya (KKP, 2011).

Limbah perikanan melalui proses autolisis pada kondisi asam dapat digunakan sebagai alternatif bahan baku pakan maupun sebagai atraktan. Hasil penelitian menunjukkan bahwa silase dapat meningkatkan kecernaan pakan karena tersedia dalam bentuk rantai peptide (Adwiyah, 2007).

Salah satu limbah perikanan yang berpotensi sebagai bahan pakan alternatif adalah ikan swanggi pada proses pengolahan surimi. Menurut Park and Morrisay
(2000), surimi merupakan proses pengolahan awal yang meliputi penyiangan untuk menghilangkan kepala, tulang, duri, kulit dan organ dalam. Ketersediaan dari limbah proses pengolahan surimi cukup banyak berdasarkan data DKP (2005). Limbah ikan swanggi tidak dapat diberikan secara langsung kepada ikan karena dapat menimbulkan efek negatif yaitu cepat rusak dan busuk sehingga perlu dilakukan untuk menambah nilai ekonomi dari limbah padat ini adalah melalui proses kimiawi dengan penambahan zat organik berupa asam formiat dan propionat (Handoko dkk., 2011).

Jumlah pakan yang dikonsumsi mempengaruhi kandungan nutrisi pada ikan. Banyaknya nutrisi pakan yang diserap oleh tubuh ikan dapat dihitung menggunakan retensi. Retensi protein merupakan gambaran dari banyaknya kandungan protein yang diberikan, yang dapat diserap atau dimanfaatkan untuk membangun maupun memperbaiki sel-sel tubuh yang rusak serta dimanfaatkan tubuh ikan bagi metabolisme sehari-hari (Buwono, 2000). Retensi lemak menggambarkan kemampuan ikan menyimpan dan memanfaatkan lemak pakan (Agustono dkk., 2007).

Berdasarkan latar belakang tersebut perlu dilakukan penelitian lebih lanjut mengenai penambahan limbah surimi ikan 
swanggi ( $P$. macracanthus) secara kimiawi terhadap retensi protein dan retensi lemak sehingga dapat dapat diketahui banyaknya nutrisi pakan yang diserap dalam tubuh ikan. Penambahan limbah surimi ikan swanggi dalam ransum pakan diharapkan dapat menjadi salah satu alternatif untuk mengurangi penggunaan tepung ikan. Tujuan dari penelitian ini adalah untuk mengetahui pemberian limbah surimi ikan swanggi secara kimiawi terhadap peningkatan laju pertumbuhan dan efisiensi pakan ikan nila (Oreochromis niloticus).

\section{Materi dan Metode}

\section{Alat dan Bahan}

Alat-alat yang digunakan pada penelitian ini terdiri dari akuarium, selang, batu aerasi, timbangan digital, penggaris, saringan, baskom, thermometer, $\mathrm{PH}$ paper, ammonia tes kit dan DO tes kit, dan spuit. Alat yang digunakan dalam penelitian tentang pertumbuhan adalah akuarium dengan tinggi $25 \mathrm{~cm}$ dan lebar $40 \mathrm{~cm}$ dan panjang $20 \mathrm{~cm}$ sebanyak 20 buah, diisi ikan sebanyak enam ekor dan diberi selang aerasi dan batu aerasi, dan selang sifon. Bahan - bahan yang digunakan dalam penelitian ini adalah benih ikan nila dengan panjang rata-rata antara 3-5 cm sebanyak 120 ekor yang diperoleh dari Mojokerto. Limbah ikan swangi diperoleh dari PT. Starfood Internasional sedangkan Asam propionat dan asam formiat diperoleh dari Brata camp.

\section{Metode Penelitian}

Penelitian ini dilaksanakan selama September - Oktober 2014 di Laboratorium Pendidikan Perikanan Fakultas Perikanan dan Kelautan dan pembuatan pakan dilakukan di Laboratorium Makanan Ternak Fakultas Kedokteran Hewan, Universitas Airlangga. Analisa proksimat pakan ikan dilakukan di Laboratorium Kimia, Universitas Muhammadiyah Malang.

\section{Prosedur Penelitian}

\section{Pengolahan secara kimia}

Limbah ikan swanggi dibersihkan selanjutnya dikeringkan dan digiling. Asam fomiat dan propionat ditambahkan sebanyak 4,5\% (sesuai dengan penelitian Erlyana, 2014). Campuran tersebut diaduk 3-4 kali setiap hari selama empat hari, kemudian hari ke-5 sampai ke-7 diaduk satu kali sehari. Setelah itu dilakukan analisis proksimat. Diaplikasikan pada ikan nila sebagai pakan subtitusi untuk mengetahui pertumbuhan dan efisiensi pakan.

\section{Pembuatan pakan perlakuan}

Bahan pakan diayak terlebih dahulu sehingga menghasilkan bahan yang lembut. Setelah semua bahan siap baru ditimbang 
sesuai dengan formulasi yang sudah memenuhi kebutuhan nutrisi pakan ikan nila. Setelah ditimbang bahan yang berukuran mikro dicampur jadi satu sampai merata atau homogen, setelah itu baru yang ukuran makro dicampur ke dalam campuran mikro satu persatu sampai merata dalam wadah atau loyang. Bahan pakan yang telah tercampur merata dimasukkan ke dalam loyang dan dikukus sampai 10 menit. Setelah adonan siap, kemudian dicetak dengan menggunakan mesin pellet atau mesin penggiling daging. Pellet yang sudah setengah jadi kemudian dikeringkan dengan suhu $60^{\circ} \mathrm{C}$ selama 24 jam dengan menggunakan oven, setelah di oven selama 24 jam pellet siap digunakan. Cara pembuatan pakan ikan nila pada tiap-tiap perlakuan $\mathrm{P}_{0}, \mathrm{P}_{1}, \mathrm{P}_{2}$, dan $\mathrm{P}_{3}$ sama dengan yang di atas.

Pakan uji yang digunakan adalah pakan buatan berbentuk pellet kering yang ukurannya disesuaikan dengan ukuran bukaan mulut ikan. Komposisi pakan antar perlakuan dihitung dengan menggunakan metode gabungan trial dan bujur sangkar (Pearson). Pakan dengan jumlah hasil pemanfaatan limbah ikan swanggi dan tepung ikan yang berbeda-beda dalam ransum pakan diberikan pada tingkat pemberian 5\% dari biomassa (Suyanto, 2010).

\section{Manajemen Kualitas Air}

Pada proses pemeliharaan udang galah dilakukan manajemen kualitas air dengan cara menyifon kotoran dan sisa pakan setiap tiga hari sekali pada pukul 15.00 WIB, serta dilakukan pergantian air sebanyak $50 \%$ saat penyifonan.

\section{Pelaksanaan Penelitian}

Penelitian ini dilakukan selama 40 hari. Pemberian pakan dilakukan sebanyak 3 kali/hari pada pukul 09.00, 12.00 dan 15.00 WIB. Jumlah pakan yang diberikan sebanyak 5\% dari biomass ikan nila. Parameter utama yang diamati adalah retensi protein dan retensi lemak ikan nila. Parameter penunjang penelitian ini adalah suhu, $\mathrm{pH}$, DO dan ammonia.

\section{Analisis data}

Metode penelitian yang digunakan dalam penelitian ini adalah metode eksperimental yang terdiri dari empat perlakuan dengan lima ulangan. Rancangan percobaan yang digunakan adalah Rancangan Acak Lengkap (RAL). Perlakuan yang digunakan dalam penelitian ini adalah sebagai berikut : $\mathrm{P}_{0}$ : pakan tanpa penambahan limbah surimi ikan swanggi; $\mathrm{P}_{1}$ : pakan dengan penambahan limbah surimi ikan swanggi sebanyak $25 \% ; \mathrm{P}_{2}$ : pakan dengan penambahan limbah surimi ikan swanggi sebanyak $50 \% ; \mathrm{P}_{3}$ : pa- 
kan dengan penambahan limbah surimi ikan swanggi sebanyak $75 \%$. Data yang diperoleh kemudian dianalisis secara deksriptif.

\section{Hasil dan Pembahasan}

\section{Retensi Protein dan Retensi Lemak}

Dari hasil penelitian didapatkan nilai retensi protein berkisar 7,97 - 11,02\% dan terdapat kenaikan retensi protein pada perlakuan P1 dan P3. Retensi protein tertinggi terdapat pada perlakuan P3 $(11,02 \%)$ dan retensi protein terendah terdapat pada perlakuan kontrol dan perlakuan P1 (9,26\%), nilai retensi lemak berkisar 4,09 - 6,73\%. Dari hasil analisa statistik menunjukkan bahwa substitusi limbah padat surimi ikan swanggi pada tepung ikan menunjukkan hasil yang tidak berbeda nyata $(p>0,05)$ terhadap retensi protein dan retensi lemak ikan nila.

Berdasarkan analisa statistik menunjukkan bahwa substitusi tepung ikan dengan silase limbah surimi ikan swanggi menunjukkan hasil yang tidak berbeda nyata (p>0,05) terhadap retensi protein nila ( $O$. niloticus). Hal tersebut menunjukkan bahwa silase limbah surimi ikan swanggi tidak dapat meningkatkan nilai retensi protein yang lebih baik dibandingkan dengan tepung ikan. Hal ini diduga karena kadar protein limbah surimi ikan swanggi $(46,3137 \%)$ hampir sama dengan tepung ikan $(47,8048 \%)$. Namun jika dilihat dari data retensi protein ada kemungkinan terdapat pengaruh dari faktor eksternal yang menyebabkan penyerapan protein menjadi terhambat. Faktor eksternal tersebut antara lain kualitas benih, kualitas air dan lokasi penelitian.

Berdasarkan data penelitian sebelumnya dapat dilihat bahwa pertumbuhan tertinggi ikan nila selama penelitian adalah 1,44\%. Pertumbuhan diasumsikan sebagai pertambahan jaringan struktural, yang berarti pertambahan jumlah protein dalam jaringan tubuh. Cepat tidaknya pertumbuhan nila ditentukan oleh banyaknya protein yang dapat diserap oleh tubuh nila sebagai zat pembangun. Hampir semua jaringan secara aktif mengikat asam-asam amino dan menyimpannya secara intra-seluler dalam konsentrasi yang lebih besar, untuk dibentuk menjadi protein tubuh (sel-sel tubuh) (Buwono, 2000).

Berdasarkan analisa statistik menunjukkan bahwa substitusi tepung ikan dengan silase limbah surimi ikan swanggi menunjukkan hasil yang tidak berbeda nyata $(\mathrm{p}>0,05)$ terhadap retensi lemak nila $(O$. niloticus). Tubuh ikan membutuhkan lemak untuk disimpan sebagai lemak struktural. Untuk memenuhi kebutuhan lemak tersebut 
maka ikan mensintesis (biokonversi) lemak berasal dari nutrea non lemak, seperti karbohidrat menjadi asam-asam lemak dan trigliserida yang terjadi di hati dan jaringan lemak (Linder, 1992).

\section{Kualitas Air}

Nilai Kisaran Kualitas Air Selama Pemeliharaan 40 Hari (Tabel 1). Menurut
Wijanarko (2002) kualitas air adalah kelayakan perairan untuk mendukung kehidupan dan pertumbuhan ikan yang ditentukan oleh fisika dan kimia air. Kualitas air harus diperhatikan agar ikan dapat tumbuh dan berkembang secara optimal. Kualitas air yang dianggap penting yaitu suhu, oksigen terlarut, $\quad \mathrm{pH}, \quad$ dan amonia.

Tabel 1 Kualitas air selama 40 hari pengamatan

\begin{tabular}{ccccc}
\hline Parameter & $\mathrm{P}_{0}$ & $\mathrm{P}_{1}$ & $\mathrm{P}_{2}$ & $\mathrm{P}_{3}$ \\
\hline Suhu $\left({ }^{\circ} \mathrm{C}\right)$ & $26-28$ & $26-28$ & $26-28$ & $26-28$ \\
Oksigen Terlarut (mg/liter) & $5-8$ & $5-8$ & $5-8$ & $5-8$ \\
$\mathrm{pH}$ & $7-8$ & $7-8$ & $7-8$ & $7-8$ \\
Amoniak (mg/liter) & $0-1,5$ & $0-1,5$ & $0-1,5$ & $0-1,5$ \\
\hline
\end{tabular}

Suhu air selama penelitian berkisar antara $27-28^{\circ} \mathrm{C}$. Pada kisaran tersebut, ikan nila (Oreochromis niloticus) dapat hidup dengan baik. Kisaran suhu tersebut sesuai dengan Khairuman dan Amri (2008), Suhu air optimal yang dibutuhkan ikan nila yaitu 25-30 C. Suhu berpengaruh pada kehidupan dan pertumbuhan ikan, suhu juga mempengaruhi kecernaan makanan, sedangkan perubahan suhu juga dapat mempengaruhi kecepatan metabolisme. Pernyataan tersebut sesuai dengan Handjojo dan Djoko Setianto (2005) yang menyatakan bahwa suhu air normal adalah suhu air yang memungkinkan makhluk hidup dapat melakukan metabolisme dan berkembangbiak.
Selama penelitian berlangsung $\mathrm{pH}$ air berkisar antara 7-8. Arie (2007) menyatakan, kisaran $\mathrm{pH}$ yang diperlukan oleh ikan nila yaitu 6-9. Dengan demikian, kisaran $\mathrm{pH}$ pada penelitian ini masih sesuai untuk kehidupan ikan nila (Oreochromis niloticus). Proses metabolisme tubuh ikan tidak terganggu karena jumlah oksigen terlarut selama penelitian masih sesuai dan tidak mengalami perubahan ekstrim untuk pemeliharaan ikan nila. Konsentrasi amoniak selama penelitian berkisar anatara 0-1,5 mg/l. Khairuman dan Amri (2008) menyatakan bahwa batas amoniak dalam perairan yang dapat membahayakan ikan apabila kadar amoniaknya melebihi $0,5 \mathrm{mg} / \mathrm{L}$ air. 
Dengan demikian kandungan amoniak pada media pemeliharaan tidak memenuhi syarat bagi kehidupan benih ikan nila (Oreochromis niloticus).

\section{Kesimpulan dan Saran}

Berdasarkan hasil penelitian, maka dapat ditarik kesimpulan bahwa substitusi silasi limbah padat surimi ikan swanggi secara kimiawi pada tepung ikan tidak berpengaruh terhadap retensi protein dan retensi lemak ikan nila (Oreochromis niloticus). Berdasarkan hasil penelitian yang telah dilakukan, perlu dilakukan penelitian lebih lanjut pada parameter-parameter yang lain untuk menentukan tingkat subtitusi tepung ikan dengan tepung ikan swanggi. Berdasarkan hasil penelitian yang telah dilakukan, substitusi silase secara kimiawi limbah padat surimi ikan swanggi (Priacanthus macracanthus) pada retensi protein paling tinggi terjadi pada perlakuan $75 \%$ sehingga diperlukan penelitian lebih lanjut, pada parameter-parameter yang lain untuk menentukan tingkat subtitusi tepung ikan dengan tepung ikan swanggi.

\section{Daftar Pustaka}

Adwiyah, R. 2007. Pengolahan dan Pengawetan Ikan. Bumi Aksara. Jakarta. 30 hal

Agustono, Lokapinasari, W. P. Al-Arief, M. A, Setyono, H. Nurhajati, T. dan
Lamid, M. 2007. Petunjuk Praktikum Nutrisi Ikan. Bagian Ilmu Peternakan fakultas Kedokteran Hewan, Universitas Airlangga, Surabaya.

Arie, U. 2007. Pembenihan dan Pembesaran Nila Gift. Penebar Swadaya. Jakarta. hal. 7-10.

Buwono, I. D. 2000. Kebutuhan Asam Amino Esensial dalam Ransum Ikan. Kanisius. Jogyakarta. hal. 11, 12, 13, 17, 18, 30.

Handoko, S Bayu dan Dharmmesta, Hani T. (2011). Managemen Pemasaran Analisis Perilaku Konsumen. Yogyakarta: BPFE.

Handjojo dan D. Setianto.2005. Patologi Ikan Teleostei. Gadjah Mada University Press, Yogyakarta.

Khairuman dan K. Amri. 2002. Membuat Pakan Ikan Konsumsi. Agromedia Pustaka. Jakarta. hal 1-17.

[KKP] Kementerian Kelautan dan Perikanan. 2010. Rencana Strategis Kementrian Perikanan dan Kelautan 2010-2014. Kementrian Kelautan dan Perikanan, Jakarta

Kusriningrum. 2008. Perancangan Percobaan. Airlangga University Press. Surabaya. hal 65-125.

Mudjiman, A. 2002. Makanan Ikan. Penebar Swadaya. Jakarta. hal. 100-151. Poultry Indonesia. 2007. Limbah Udang Pengganti Tepung Ikan. http://www.poutryindonesia. - com/ 5 / 09 /2008. 1 hal.

Park, J. W., and Morrissey, M. T. 2000. Manufacturing of Surimi From Light Muscle Fish. Edited by Park J. W.

Surimi and Surimi Seafood. New York: Marcel Dekker Inc.

Suyanto, 2002. Nila. Penebar Swadaya. Jakarta. Hal 1- 6. 